\title{
Robot cellába illeszthetö ATmega2560 mikrokontroller vezérelt tesztpanel tervezése \& készítése oktatási céllal
}

\author{
Vinnai Bence \\ Mechatronikai Tanszék \\ Debreceni Egyetem, Müszaki Kar \\ Debrecen, Magyarország \\ vinnai.bence@gmail.com
}

\author{
Erdei Timotei István \\ Mechatronikai Tanszék \\ Debreceni Egyetem, Müszaki Kar \\ Debrecen, Magyarország \\ timoteierdei@eng.unideb.hu
}

\author{
Husi Géza \\ Mechatronikai Tanszék \\ Debreceni Egyetem, Müszaki Kar \\ Debrecen, Magyarország \\ husigeza@eng.unideb.hu
}

\begin{abstract}
Absztrakt - Jelen írás témája egy oktatási célra tervezett és készített tesztpanel, amely KUKA KR5 robot köré épült robot cella vázra illeszthető, és Atmel mikrokontroller vezérléssel múködik. Bemutatásra kerül a panel felépítése, múködése, a tervezés és az elkészítés folyamata. A panel a Debreceni Egyetem, Mechatronikai Tanszék, robot laborjában került tesztelésre.
\end{abstract}

Kulcsszavak- Arduino; KUKA; tesztpanel; nyomtatott áramkör;

\section{BEVEZETÖ}

A Debreceni Egyetem, Müszaki Kar, Mechatronikai Tanszékének Robot laboratóriumában zajlik a mechatronikai mérnök szakos hallgatók gyakorlati oktatása a Robottechnika témakörében [16]. A laboratóriumban többek között található egy KUKA KR5 [5] típusú ipari robot, amely segítségével a hallgatók a robotikáról tanult elméleti tudásukat átültethetik a gyakorlatba. A robot labor folyamatos fejlesztésen megy keresztül. A KUKA KR5 robot is részt vesz ezekben a fejlesztésekben, például új szerszám egységet kapott, és a közelmúltban egy robot cella vázzal egészült ki. Ezeknek a fejlesztéseknek a célja az oktatás minőségének folyamatos javítása. A tervezett és elkészített tesztpanel is ennek okán, jött létre. Segítségével újfajta feladatok végezhetők el, segítve ezzel a tapasztalatszerzést. Célja, hogy felhasználva az oktatás során, a hallgatók önálló munkavégzését, és ismereteik elmélyítését segítse, tegye lehetővé az autodidakta tanulást.

A tesztpanelt Arduino ATmell [1] mikrokontroller vezérléssel lett ellátva el. Mivel az Arduino, felépítéséből adódóan, könnyen és viszonylag olcsón beszerezhető, és használata is könnyedén tanulható, flexibilis eszközként van jelen.

A feladat gyakorlati kivitelezése előtt irodalomkutatást került elvégzésre, a KUKA KR5 ipari hegesztő robotot kapcsán. Tanulmányozásra került a robot cella váza, majd megtervezésre a tesztpanel szerkezeti kialakítását, és annak működése. Ezután megtervezésre került az áramköri kapcsolás, készítve lett egy háromdimenziós terv a panelról, amihez PCB is legyártásra került.

Illetve szimulálásra került az ATmega mikrokontroller-re írt program.
Végül fel lettek szerelve a panelokat a robot cella vázra, és a robottal együtt tesztelésre került. A kutatás/fejlesztésnek a Debreceni Egyetem adott otthont [14][15].

\section{ATMEGA2560 MIKROKONTROLLER}

Az Arduino platform története 2003-ig nyúlik vissza. Kolumbiában Hernando Barragán létrehozta a Wiring platformot diplomamunkájaként, majd ezt nyílt forráskód alatt közzé tette. A platform azóta is aktív, bár nem örvend akkora sikernek, mint az Arduino, ami a Wiring alapján készült. Maga az Arduino platform 2005-ben született meg Massimo Banzi és Casey Reas munkájának gyümölcseként. A platform a nevét az Olaszországi Ivrea városának történelmi alakjáról, Arduin of Ivrea-ról kapta. Az Arduino szó magyarul "bátor barát"-ot jelent [1].

Az első board megjelenésétől kezdve az Arduino platform egyre nagyobb és népszerübb lett, köszönhetően az „Open Source" filozófiának.

$\mathrm{Az}$ Arduino IDE fejlesztőkörnyezet ingyenesen hozzáférhetö.

Napjainkban sokféle Arduino board közül választhatunk attól függően, hogy mennyire komplex és kiterjedt a feladat, amit el akarunk végezni, (pl. Linux disztribúció futtatása, wifi kapcsolat, stb.). A feladat szempontjából Arduino Mega 2560 Rev3 panel lett kiválasztva [8].

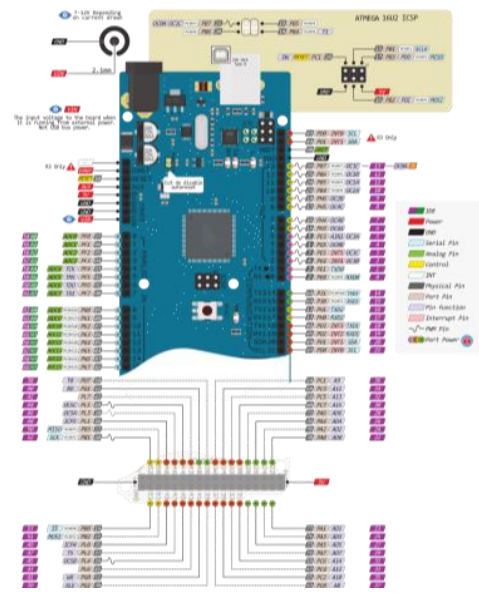

1. ábra: Arduino MEGA 2560 Rev 3. [8] 
Az Arduino Mega 2560 az eredeti Arduino Mega továbbfejlesztett változata. $\mathrm{Az}$ eredeti Mega board az ATmega1280 mikrovezérlö köré épült, míg az új változat az ATmega 2560 vezérlőt használja. Összesen 54 digitális I/O pin található rajta, melyekből 15 használható PWM kimenetként, ezen felül 16 analóg bemenettel is rendelkezik. A $16 \mathrm{MHz}$-es oszcillátor és a $256 \mathrm{~KB}$ Flash memória alkalmassá teszi nagyobb projektekhez való felhasználását. [2] $\mathrm{Az}$ Arduino Mega panelt kialakításából adódóan az összetettebb, több ki-, és bemenetet használó projektek esetén használják. Ilyenek például a házilag készült robotok, drónok, vagy $3 \mathrm{D}$ nyomtatók.

$\mathrm{Az}$ Arduino programozására keresztplatformos Java, $\mathrm{C} / \mathrm{C}++$ nyelven történik, amit gépi kódra fordítunk, amit a mikrovezérlő kezelni tud. A mikrovezérlők (néhány kivétellel) mind az Atmel által gyártott AVR család tagjai [3].

$\mathrm{Az}$ Arduino program két fö részből áll egy Arduino program:

- $\quad \operatorname{setup():~A~program~futtatása~során~ez~fut~le~}$ először. A kódban legelőször a változókat deklaráljuk, a setup() funkciót ez után szokás elhelyezni. Ez az első függvény, ami lefut a programban, csak egyszer fut le és az $\mathrm{I} / \mathrm{O}$ csatlakozókat, vagy a soros kommunikációt állítjuk be vele.

- $\operatorname{loop}()$ : Ez a rész (ahogy a neve is mutatja) folyamatosan ismétlődik - a bemenetek olvasása, kimenetek vezérlése, számítások, stb. Itt történik (majdnem) minden, a munka nagy része [4].

\section{KUKA KR5 ARC}

A KUKA 1898-as indulása óta napjainkra a világ egyik vezető ipari robot gyártó és fejlesztő vállalata lett [5]. Bár a kezdetekkor még többféle dologgal foglalkoztak (az írógépektől a szemétszállító jármüvekig), fő találmányaik az automatikus hegesztéshez kapcsolódtak. 1973-ban mutatták be a történelmi jelentőségü FAMULUS robotot, amely az első, hat elektromechanikailag meghajtott tengellyel rendelkezö ipari robot. Legújabb fejlesztéseik közé tartozik az LBR iiwa robotcsalád. Ez a világon az első olyan könnyüépítésü robot, ami ipari felhasználásra alkalmas. A robot különlegessége hogy minden tengelyében érzékelők vannak [6].

A KUKA KR5 egy korábbi robotcsaládból származik, alapvetően hegesztési munkákra fejlesztették ki, de más feladatokat is el tud végezni.

TÁBLÁZAT I. KUKA KR5 SPECIFIKÁCIÓK

\begin{tabular}{|c|c|}
\hline Terhelhetőség & $5 \mathrm{~kg}$ \\
\hline Maximum terhelés & $37 \mathrm{~kg}$ \\
\hline Axisok száma & 6 \\
\hline Rögzítési pontok & Talaj, Cella \\
\hline Vezérlő típus & $\mathrm{KR} \mathrm{C} 2$ \\
\hline Súly & $127 \mathrm{~kg}$ \\
\hline Üzemi hőmérséklet & $+10 \mathrm{C}-+55 \mathrm{C}$ \\
\hline
\end{tabular}

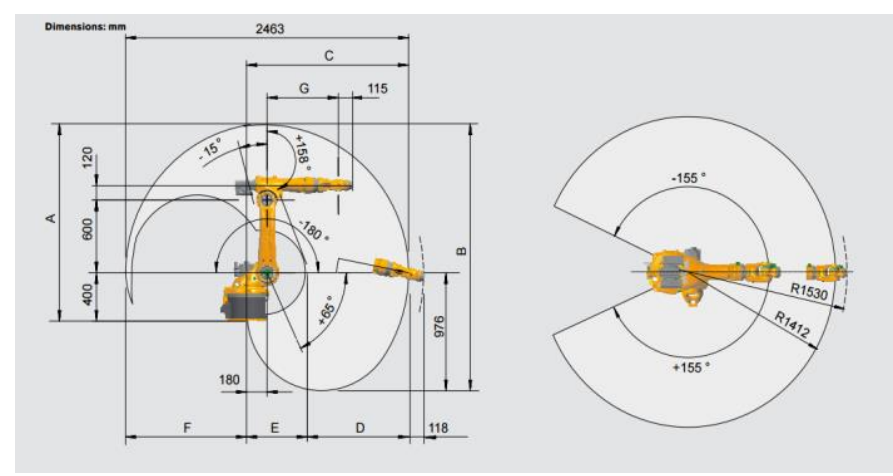

2. ábra: KUKA KR5 Arc munkatere [7]

A KUKA KR5 hat tengellyel rendelkezik. Maximális sebessége $2 \mathrm{~m} / \mathrm{s}$. Az ipari hegesztő robotkar munkaterét elsődlegesen az axisok határozzák. A robot sebessége tengelyekre lebontva.

- Axis $1(\mathrm{~A} 1) 154 \% \mathrm{~s}$

- Axis 2 (A2) $154 \%$

- $\quad$ Axis $3(\mathrm{~A} 3) 228^{\circ} / \mathrm{s}$

- $\quad$ Axis 4 (A4) $343 \%$

- $\quad$ Axis 5 (A5) $384 \%$

- Axis 6 (A6) $721 \%$ s [10].

\section{ATMEGA2560 MIKROKONTROLLER TESZTPANEL SZIMULÁCIÓJA \& 3D TERVE}

Az oktatási panel két fő részből áll, az egyik a fő panel, ami a vezérlés feladatát látja el. Ezen található az ATmega2560 mikrokontroller, továbbá a 4 darab vezérlő nyomógomb, egy hibajelző LED, és a csatlakozók, amiken keresztül a többi panelhez tud csatlakozni [9].

A másik részét a munkapanelek alkotják. Ezekből négy darab van, mindegyikükön csatlakozók, két darab LED és egy nyomógomb található.

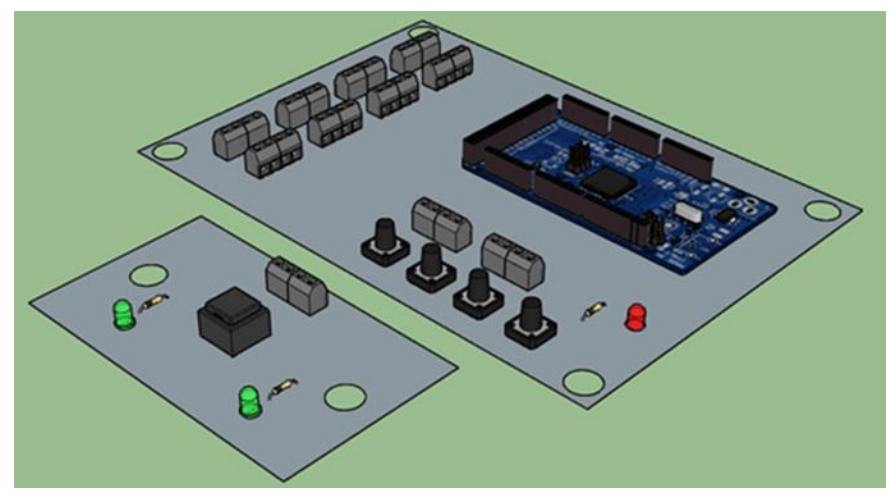

3. ábra: Oktatási modul 3D terve

A 3D modell elkészítésének, egyik fö oka az volt, hogy végleges összeszerelt egységeket láthassuk. Illetve, egy esetleges doboz terv készítésekor alkalmazni tudunk 3D nyomtatási technológiát. 
A megírt program müködését tekintve, indításkor generál egy feladatot, ami a következöképpen épül fel: a négy munkapanel között felállít egy véletlenszerü sorrendet. Egy munkapanel többször is következhet, akár egymás után is. Az első munkapanel egyik LED-je világít, ez jelzi, hogy az ezen a panelen lévő gombot kell megnyomnia a robotnak. Amikor a gomb lenyomva van, a másik LED jelzi, hogy a program észlelte a gomb lenyomását, és jó gomb van lenyomva. Ha a helyes gombot nyomja meg a robot, azután a sorrendben következő panel LED-je világít, és így tovább. Ha rossz gombot nyom meg a robot, akkor a fö panelen lévő piros hibajelző LED világít, majd a program újraindul. Összesen 8 lépés van, ha mindet helyesen teljesítjük, akkor minden panelen kigyullad egy-egy LED, ezzel jelezve, hogy a feladat véget ért. Ekkor, mint a program futása közben bármikor a fö panelen lévő vezérlő gombokkal adhatunk utasítást az Arduino-nak. A gombok funkciója a következőképpen alakul:

- $\quad$ Reset: újraindítja az aktuális feladatot

- Új feladat: új véletlenszerüen generált feladatot készít, és aktiválja

- 1. előre megírt feladat

- 2. előre megírt feladat

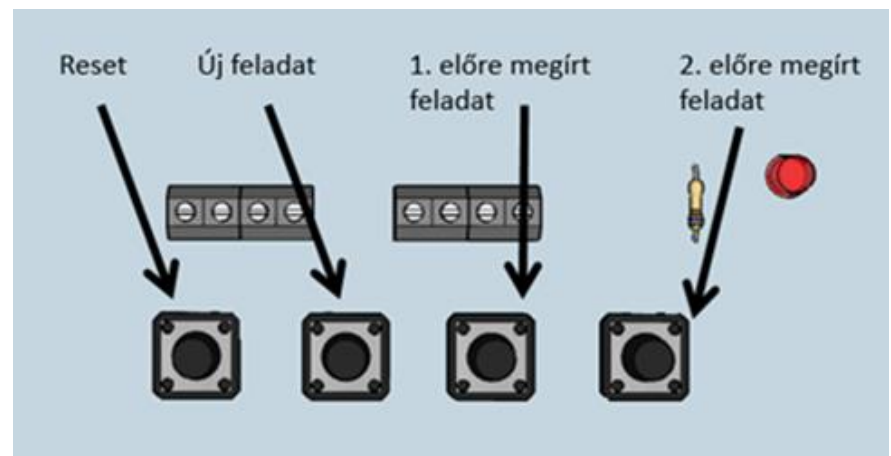

4. ábra: A vezérlő nyomógombok

$\mathrm{Az}$ elöre megírt feladatokat az adott nyomógombbal tölthetjük be. Ez azért fontos, mert ezeket a feladatokat bármikor megismételhetjük, míg a véletlenszerüen generált feladatokat nem tudjuk biztosan megismételni, ha már másik feladat lett betöltve.

Az elöre programozott feladatok ugyanúgy futnak le, mint a véletlenszerűen generáltak. A program futásának folyamatábráját a 3 . ábra mutatja be.

A tesztpanelek áramkörének fejlesztésénél a Tinkercad online tervező felülete biztosított lehetőséget. A Tinkercad az Autodesk tulajdona, így Autodesk profillal belépve rögtön elérhetjük a már korábban készített kapcsolásainkat. A Circuits oldalt használhatjuk áramkor tervezésére. Itt grafikus felületen helyezhetjük el az alkatrészeket, és köthetjük össze öket. Egy forrasztásmentes próbapanel szimulációja történik. $\mathrm{Az}$ áramkörhöz az egyszerü ellenállástól az integrált áramkörökön át az Arduino UNO-ig sokféle alkatrészt hozzáadhatunk. Ezen felül elöre összeösszeállított egyszerübb áramköröket is beilleszthetünk/szimulálhatunk [11].

A Code Editor gombra kattintva megjelenik egy Arduino fejlesztői környezet, amivel az áramkörben lévő Arduino panel programját írhatjuk meg. Ebben a fejlesztői környezetben szinte minden megvan ami a hivatalos Arduino IDE-ben megtalálható. A kódot lefordíthatjuk, ekkor a weboldal jelez, ha valamilyen hibát vétettünk. Rátölthetjük a programot a szimulált Arduino-ra, vagy ki is exportálhatjuk az Arduino panelek által használt .ino kiterjesztésű fájlba, amit a valódi panelra tölthetünk fel. A szimuláció egy kiemelt funkció, mivel egy esetleges hiba esetén nem teszünk kárt a tényleges eszközökben, a hiba gyorsabban kereshetö és kijavítható.

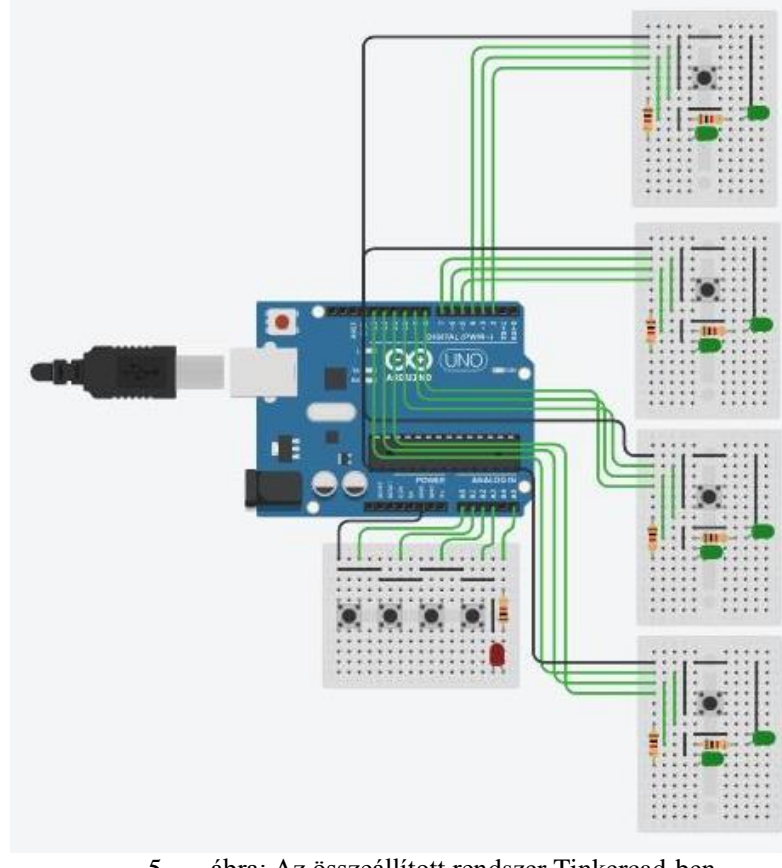

A panelok úgy lettek kialakítva, hogy az alumínium profilhoz könnyedén csatlakoztatható legyen. Ezzel a konstrukcióval nagyobb mértékben kihasználhatjuk a KUKA KR5 robot mozgásterét és képességeit.

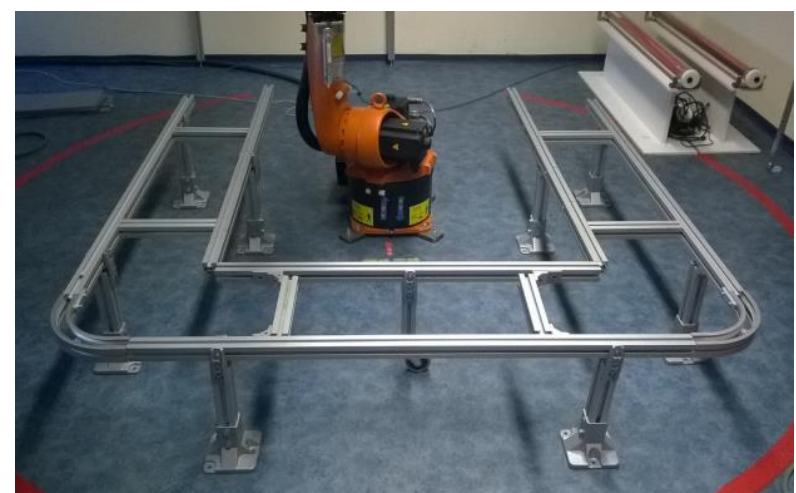

6. ábra: KUKAK R5 V0.1 robot cella

A tesztelésekhez szükség volt előre meghatározott feladatok felprogramozására is, ezért került a programba kettő előre megírt feladat. A kész panel-rendszer a robottal való tesztelésekor ezek a feladatok nagyon hasznosnak bizonyultak. 
Az áramkör kialakítása során a nyomógombok elé nem került felhúzó ellenállást, helyette az Arduino beépített felhúzó ellenállása lett használva. Ennek aktiválása úgy történt, hogy a programban a nyomógombok állapotát figyelő bemenetet „,input” típus helyett ,input_pullup” típusként lett deklarálva,

A végleges kialakítás szerint minden munkapanel 4 vezetékkel csatlakozik a fö panelhoz. Ezek a két LEDet vezérlő kimenet, a nyomógomb állapotát figyelő bemenet, és a GND.

Az Arduino Mega 2560 panelen használt a kiosztás II. táblázatban kerül összefoglalásra.

\section{VEZÉRLŐ PROGRAM BEMUTATÁSA}

Ebben a részben a tesztpanelt vezérlő program struktúráját kerül bemutatásra.

A program elején a ,setup()" függvény előtt konstansként lett deklarálva a változókat, értékül a hozzájuk tartozó ki-, bemeneti lábat lett megadva. Később ezekkel a nevekkel

TÁBLÁZAT II. ARDUINO MEGA 2560 REV3 KIOSZTÁs

\begin{tabular}{|c|c|c|}
\hline $\begin{array}{c}\text { Arduino } \\
\text { kimenetek és } \\
\text { bemenetek } \\
\text { kiosztása }\end{array}$ & Funkció & $\begin{array}{c}\text { MEGA } \\
\text { pin }\end{array}$ \\
\hline btn1 & 1-es panel nyomógomb & 23 \\
\hline btn2 & 2-es panel nyomógomb & 22 \\
\hline btn3 & 3-as panel nyomógomb & 29 \\
\hline btn4 & 4-es panel nyomógomb & 28 \\
\hline LED1 & 1-es panel LED & 25 \\
\hline LED2 & 2-es panel LED & 24 \\
\hline LED3 & 3-as panel LED & 31 \\
\hline LED4 & 4-es panel LED & 30 \\
\hline aLED1 & 1-es panel visszajelzés & 27 \\
\hline aLED2 & 2-es panel visszajelzés & 26 \\
\hline aLED3 & 3-as panel visszajelzés & 33 \\
\hline aLED4 & 4-es panel visszajelzés & 32 \\
\hline errorLED & hibajelzés & 6 \\
\hline resetbtn & reset & 2 \\
\hline newtskbtn & új feladat generálás & 3 \\
\hline task1btn & 1-es elöre programozott feladat & 4 \\
\hline task2btn & 2-es elöre programozott feladat & 5 \\
\hline-- & GND & GND \\
\hline
\end{tabular}

Következő lépésként definiálva lett a nyomógombok állapotát tároló változók; a „state”, ami az éppen aktív panel sorszámát veszi fel értékként, és a feladat tárolására alkalmazott „task” vektort. A vektor 8 elemet tartalmaz, ezek az elemek tárolják el az éppen aktuális feladat sorrendjét: az első elem mutatja melyik panel az első, a második elem mutatja melyik panel a második, és így tovább.

A „setup()” függvényben csupán a csatlakozók kommunikációs irány szerinti beállítása történik a „,pinMode” parancs alkalmazásával. A kimeneti csatlakozókat (LED vezérlés) „output”-ra, a bemeneti csatlakozókat (nyomógombok) a már korábban említett okokból ,input_pullup” módra állítottam, Már ebben a részben is az előzőekben megadott névvel hivatkozok az adott csatlakozóra.

A „loop()” funkció egy új feladat generálásával indul. Ezáltal a „task[i]” vektor feltöltődik a feladat lépéseivel. Kezdéskor $\mathrm{i}=0$, majd minden sikeres lépés után eggyel nö, amíg eléri a 7-et, akkor a feladat véget ér. A state változó mindig az aktuális feladat aktuális lépésének megfelelő értéket vesz fel. Ehhez képest vizsgálva a nyomógombokat, a program eldönti, hogy jó, vagy rossz nyomógombot nyomtak meg, esetleg vezérlő gomb nyomása történt. A program bármelyik szakaszában müködtethetjük a vezérlö gombokat, tehát újraindíthatjuk a feladatot, új feladatot generálhatunk, vagy betölthetjük a két előre programozott feladat egyikét.

A „loop()” függvényen kívül találhatóak azok a függvények, amelyeket a „loop()” meghív bizonyos esetekben. Ilyenek a vezérlőgombok funkciói, és a hibajelzés.

\section{EAGEL PCB TERV TERVEZÉSE}

A nyomtatott áramkör megtervezésére az EAGLE program lett választva, annak az oktatási verziója. Az EAGLE az Autodesk Inc. kapcsolási rajz-, és nyomtatott áramkör tervező programja [12]

A kapcsolási rajz készítő felületen egyszerüen tervezhetjük meg az áramköröket. Az EAGLE könyvtáraiból rengeteg alkatrészt illeszthetünk be, ha mégsem találnánk számunkra megfelelőt, „lbr” állományként újabb könyvtárakat adhatunk hozzá a programhoz. Az alkatrészeket elnevezhetjük, értéket adhatunk nekik, és összekötve őket kialakíthatjuk az áramkörünket.

$\mathrm{Az}$ alkatrészek elrendezése után a vezetősávokat kialakíthatjuk kézzel, vagy az ,autorouter” segítségével, ami több lehetséges vezetősáv-elrendezést mutat be, amikből választhatunk és módosíthatjuk is azokat.

A „Szerkesztés - Vezeték osztályok” menüpontban beállíthatjuk a vezetősávok vastagságát, a köztük lévő minimális távolságot és a furatok átmérőjét. Ezek a paraméterek a későbbi PCB gyártás során lesznek fontosak.

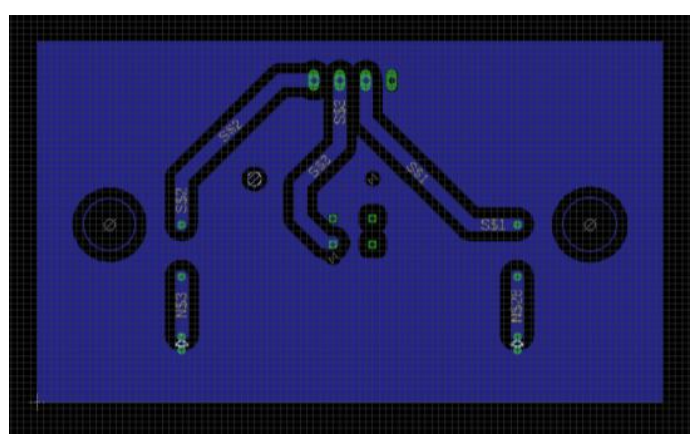

7. ábra: Oktatási tesztpanel ,al modul” 
$\mathrm{Az}$ áramköri terv elkészítése után vasalásos módszerrel került legyártásra.

Első lépésként méretre kell vágnunk a PCB lapot. Ezután a lap tisztítása következik, finomszemcsés csiszolópapírral és egy kis folyékony szappannal.

A tisztítás után következik az elöre kinyomtatott nyomtatott áramköri rajz „felvasalása” a réz felületre. Nagyon fontos hogy a rajzot lézernyomtatóval, fényes münyomó papírra nyomtassuk, mert így marad a papír felületén a legtöbb festék, ami majd a vasalás során a rézfelületre fog tapadni.

A vasalót $200-230{ }^{\circ} \mathrm{C}$-ra melegítjük, majd a kinyomtatott PCB tervet a PCB lap réz felületére helyezzük a nyomtatási oldallal lefelé. Először csak melegítve a papíron keresztül a panelt, majd lassú mozdulatokkal „felvasaljuk” a rajzolatot a rézrétegre. A vasalás után a felesleges papírréteget eltávolítjuk, a festék rajta marad a rézrétegen, és a következő lépés a maratás.

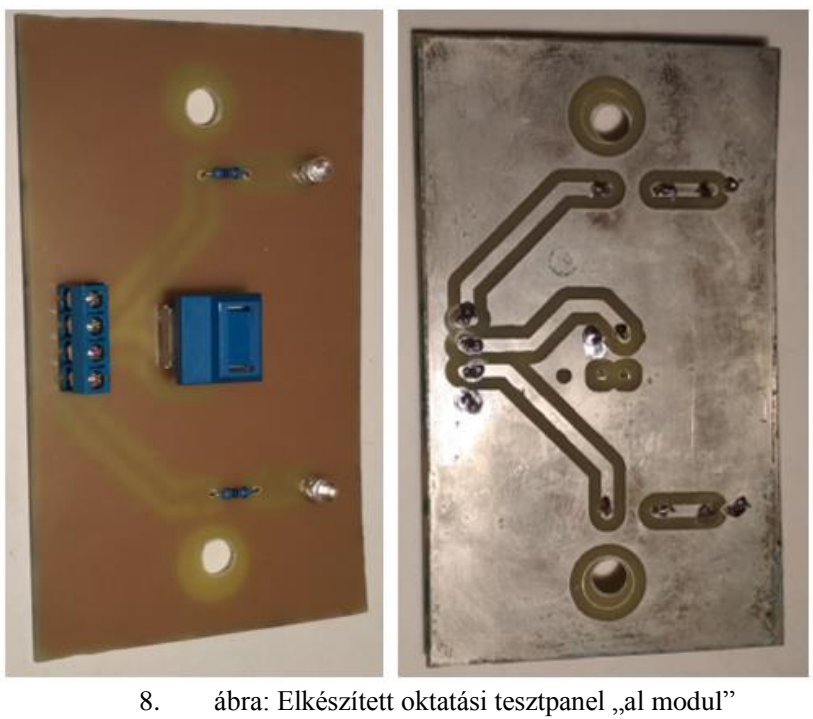

A maratás után a tintát hígítóval eltávolítjuk a PCB lapról, felfedve ezzel a kialakult vezetősávokat. Egy alapos tisztítás után érdemes a panelt ónozó folyadékkal kezelni. Az ónozás a maratáshoz hasonlóan történik annyi különbséggel, hogy más folyadékot használunk. Az ónozás védi a panelt, és könnyebbé teszi a későbbi forrasztást.

Végül be kell szerelnünk az alkatrészeket a panelba. Ehhez furatszerelt alkatrészek esetén először ki kell alakítanunk a furatokat. Felületszerelt alkatrészek esetén rögtön forraszthatunk.

\section{OKTATÁSI TESZTPANEL ÖSSZESZERELÉSE ÉS TESZTELÉSE}

A PCB lapok elkészítését követően a Debreceni Egyetem, Mechatronikai Tanszék Robot laboratóriumában került sor a tesztelésekre.

A teszteléshez a KUKA KR5 ipari hegesztő robottal került tesztelve. Első lépésként fel lettek szerelve panelek a robot cella vázra. A robot cella szabványos $40 \times 40 \mathrm{~mm}$-es alumínium profilokból áll [13]. A panelek rögzítésére $6 \mathrm{~mm}$ átmérőjü, belső kulcsnyílású csavarokat és T-nútos a PCB-t használtam. Ehhez előtte ki kellett alakítani a furatokat, a tervezés során megjelölt helyeken. A panel és az alumínium profil közé szigetelést lett téve, a tesztelési időszak alatt.

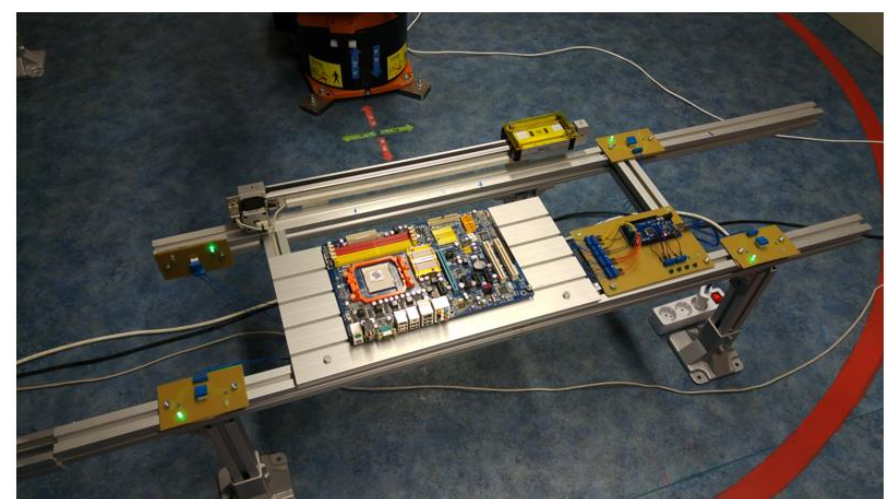

9. ábra: Elkészített oktatási tesztpanel „al modul”

A tesztpanel rendszer moduláris kialakításából adódóan egymástól bármilyen távolságra, és bármilyen helyzetben felszerelhetők a munkapanelek a robot cella vázra. A teszteléshez az egyik panelt az alumínium profil belső felületére lett szerelve, így a robotnak egy másik irányból, vízszintes mozgással kellett megnyomnia.

A tesztelés során a funkciók gyors ellenőrzése után az elöre megírt programok kerültek használatra, amelyek bármikor újra betölthetők. A KUKA KR5 robot pozícióinak felvétele és a mozgások programozása után a robot végigment a feladaton hiba nélkül. A függölegesen felszerelt panel gombját is meg tudta nyomni, bizonyítva ezzel hogy a mozgásteréből adódóan többféle pozícióban lévő panelt elér. Később teszt képen elö lett idézve egy olyan eset, amikor a robot hibázik, rossz gombot nyom meg. Ekkor a fö panelen lévő hibajelző LED kigyulladt, majd 2 másodperc múlva a feladat újrakezdődött.

\section{VIII. ÖSSZEFOGLALÁS}

A robot cellába illeszthető ATmega2560 mikrokontroller vezérelt tesztpanel elkészítésre került oktatási célra. A Debreceni Egyetem, Mechatronika Tanszék, Robot Laborjában elvégzésre kerültek a tesztek.

A panel lehetőséget biztosít arra, hogy pályabejárási gyakorlatokkal lehessen oktatni a KUKA KR5 robottal, vagy más robot egységgel. Mivel Atmel mikrokontrollerre épít, így flexibilis és más vezérlések is tesztelhetőek rajta.

A hallgatók számára az előre megírt feladatokkal az alapvető mozgások és pozícionálások begyakorolhatók, a véletlenszerüen generált feladatok pedig az egyéb pályabejárási folyamatokat, programozási módszereket és a koordinátarendszerek gördülékenyebb használatát sajátíthatják el. Mivel a munkapanelek a cellán belül bárhol és bárhogyan elhelyezhetők, újabb és újabb feladatokat oldhatnak meg a hallgatók.

\section{KÖSZÖNETNYILVÁNÍTÁS}

A publikáció elkészítését az EFOP-3.6.1-16-2016-00022 számú projekt támogatta. A projekt az Európai Unió támogatásával, az Európai Szociális Alap társfinanszírozásával valósult meg. 
Ezúton szeretnék köszönetet mondani Erdei Timotei István témavezetőmnek, hogy elvállalta, hogy konzulensem lesz, hogy a rendelkezésemre bocsátott minden szükséges eszközt és információt a szakdolgozat elkészítéséhez, és a folyamatos segítségért és támogatásért.

\section{HIVATKOZÁSOK}

[1] „Az Arduino platform”, https://malnapc.hu/arduino/az-arduino-platform/ [Hozzáférés dátuma: 2018.04.30]

[2] „Arduino Mega $2560 \mathrm{rev}$ 3”, Ihttps://store.arduino.cc/arduino-mega2560-rev3 [Hozzáférés dátuma: 2018.04.30]

[3] Maik Schmidt: Arduino. Pragmatic Programmers LLC., USA, 2011

[4] Tianhong Pan, Yi Zhu: Designing Embedded Systems with Arduino. Springer Nature Singapore Ltd., Singapore, 2017

[5] „A KUKA története”, https://www.kuka.com/hu-hu/a-kuka$\mathrm{r} \% \mathrm{C} 3 \% \mathrm{~B} 31 / \mathrm{t} \% \mathrm{C} 3 \% \mathrm{~B} 6 \mathrm{rt} \% \mathrm{C} 3 \% \mathrm{~A} 9$ net [Hozzáférés dátuma: 2018.05.03]Y. Yorozu, M. Hirano, K. Oka, and Y. Tagawa, "Electron spectroscopy studies on magneto-optical media and plastic substrate interface,” IEEE Transl. J. Magn. Japan, vol. 2, pp. 740-741, August 1987 [Digests 9th Annual Conf. Magnetics Japan, p. 301, 1982].

[6] KUKA Roboter GmbH: KUKA KR5 arc Specification. Zugspitzstrasse 140 D-86165 Augsburg Germany, 2016. KUKA Roboter GmbH: KUKA KR5 arc Specification. Zugspitzstrasse 140 D-86165 Augsburg Germany, 2016.

[7] Pub Spez KR5 arc en, KUKA Roboter GmbH Zugspitzstrasse 140 D86165 Augsburg Germany 2016.
[8] „Arduino Mega 2560” [Online]. (2016, Június 5).Available: https://store-

cdn.arduino.cc/usa/catalog/product/cache/1/image/500x375/f8876a31b6 3532bbba4e781c30024a0a/a/0/a000067_iso_1.jpg

[9] „Arduino Mega 2560” [Online]. (2016, Június 5).Available: file:///C:/Users/prince/Downloads/Spez_KR_5_arc_en.pdf

[10] KUKA KR5 Arc [Online]. (2016, Június 5).Available: https://www.kuka.com/-/media/kuka-

downloads/imported/48ec812b1b2947898ac2598aff70abc0/spez_kr_5_a rc_en.pdf

[11] KUKA KR5 Arc [Online]. (2016, Június 5).Available: https://www.tinkercad.com/

[12] EAGEL [Online]. (2016, Június 5).Available: https://www.autodesk.com/products/eagle/overview

[13] Aluminium Profil [Online]. (2016, Június 5).Available: https://alucentrum.hu/

[14] T. I. Erdei, Zs. Molnár, N. C. Obinna, G. Husi, „Cyber physical systems in mechatronic research centre," MATEC Web Conf. Volume 126, 2017.

[15] Zs. Molnár, T. I. Erdei, N. C. Obinna, G. Husi, „A novel design of an air-cushion vehicle and its implementation," MATEC Web Conf. Volume 126,

[16] T. I. Erdei, Zs. Molnár, G. Husi, „Robot visual and virtual control technology In industrial environment," WoS (Web of Science) publication, International Symposium on Small-Scale Intelligent Manufacturing Systems (SIMS ), Narvik, NORWAY- IEEE, Jun 21-24, 2016. 